\title{
Diversity of Cropping Pattern in Bogra
}

\author{
A B M J Islam ${ }^{1 *}$, S M Shahidullah ${ }^{1}$, A B M Mostafizur ${ }^{1}$ and A Saha ${ }^{1}$
}

\begin{abstract}
With a view to document the existing cropping patterns, cropping intensity and crop diversity, a study was carried out over all the upazilas of Bogra agricultural region during 2015-16. A pre-tested semi-structured questionnaire was properly used for this purpose. In the findings it was recorded that $21.88 \%$ of net cropped area (NCA) of the region was occupied by the cropping pattern Boro-Fallow-T. Aman. This pattern was found to be distributed over 27 upazilas out of 35 . The second largest area, $13.26 \%$ of NCA, was covered by Potato-Boro-T. Aman, which was spread over 17 upazilas. A total of 177 cropping patterns were identified in the whole region in this investigation. The highest number of cropping patterns was identified 36 in Nandigram upazila and the lowest was six in Dupchachia and Kahalu upazila of Bogra district. The lowest crop diversity index (CDI) was reported 0.718 in Raiganj upazila of Sirajganj district followed by 0.734 in Kalai of Joypurhat. The highest value of CDI was observed 0.978 in Pabna sadar followed by 0.972 in Bera upazila. The range of cropping intensity values was recorded 183-291\%. The maximum value was for Khetlal upazila of Joypurhat district and minimum for Bera of Pabna. As a whole the CDI of Bogra region was calculated 0.966 and the average cropping intensity at regional level was $234 \%$.
\end{abstract}

Key words: Diversity index, land use, cropping system and flash flood

\section{INTRODUCTION}

A total of 35 upazilas of four districts formed the Bogra agricultural region. It has a wide diversity in land topography and soil characters ranging from river-eroded area to Barind Tract. This region belongs to Tista Meander Floodplain (AEZ-3), Karatoa-Bangali Floodplain (AEZ-4), Lower Atrai Basin (AEZ5), Active Brahmaputra-Jamuna Floodplain (AEZ-7), Active Ganges Floodplain (AEZ10), High Ganges River Floodplain (AEZ-11), Low Ganges River Floodplain (AEZ-12), Level Barind Tract (AEZ-25) and North-eastern Barind Tract (AEZ-27) (FAO, 1988).

Majority area of this region is very suitable for agricultural crop production especially in cereals and vegetables. The cropping intensity is much higher than the other region of the country. Shortage of surface water, serious flooding and river erosion are location-specific critical problems. Low moisture-holding capacity, low organic matter content and low natural fertility are special characters of the Barind Tract.

Cropping system is the crop production activity of a farm which includes all cropping patterns grown on the farm resources, other household enterprises and the physical, biological, technological and socioeconomic factors or environments. A cropping pattern is the yearly sequence, temporal and partial arrangement of crops in a given land area. It is dependent on physical, historical, social, institutional and economic factors as well as government policies (Agrawal and Kassam, 1976). The cropping pattern and the changes therein depend on a large number of factors like climate, soil type, rainfall, agricultural technology, availability of irrigation facilities and other inputs, marketing and transport facilities and growth of agro-industries (Neena, 1998; Gadge, 2003; Rashid et al., 2005).

The yields of cereal crops are tending to stagnation, even in favourable environments. Moreover, cultivable land area is decreasing

${ }^{1}$ Rice Farming Systems Division, BRRI, Gazipur; *Corresponding author's E-mail: saurov.brri@gmail.com 
day by day in the country. To increase the system productivity of the total environment it needs to bring diversity in enterprises for better utilization of limited resources. Detailed information on land situation and cropping systems is a prerequisite for a fruitful development programme. Diversified cropping pattern may be an option for the farmers as a coping strategy against risks (Mandal and Bezbaruah, 2013). Typology of different cropping systems is the base for the managers of these systems to intensify production (Shriar, 2000). There is a strong need for judicious and appropriate use of limited resources in case of intervention selection that does not lead to increased mal adaption or inequity in the society over long term. Existing trends of available agricultural lands is most essential requirement for any land use planning related to farming and food security in a sustainable manner. Therefore, an increased understanding of arable land use based on the cropping system is essential for the appropriate intervention in sustainable way. In these contexts, existing cropping patterns along with their diversity of such complex agricultural region are very crucial for risk minimization and overall productivity improvement. The specific objectives of the present study were to:

- Understand the existing cropping patterns scenario in Bogra region

- Visualize the existing land use pattern at upazila and regional level

- Determine the crop diversity and cropping intensity at local and regional level.

\section{METHODOLOGY}

Thirty-five upazilas of Bogra, Joypurhat, Pabna, and Sirajganj districts under Bogra agricultural region were the locale of this study. Data were collected using double stage procedure. At initial stage, data were collected through pretested semi-structured questionnaire from 35 pre-assigned Sub-Assistant Agriculture Officers (SAAO) of each upazila during October 2015 at upazila level. SAAOs were purposively pre- selected by Agriculture Extension Officers (AEO), Additional Agriculture Officer (AAO) and Upazila Agriculture Officer (UAO) or altogether. Prior to data collection, the pre-tested questionnaire was explained along with proper guidelines to the AEOs or UAOs or both and handed over to them at each Deputy Director's office of Department of Agricultural Extension (DAE) during monthly meeting for the sake of accurate data collection. The filled questionnaires were collected by the scientists of RFS Division, checked and analyzed to find the inconsistencies of the supplied data before validation workshop. All the inconsistencies among the information were documented. The collected data along with documented inconsistencies were discussed in district level workshop for necessary correction and validation. Second stage of data collection was a day-long data validation workshop at district level. The workshop dates were 26 November 2015 for Sirajganj; 14 January 2016 for Bogra; 2 February 2016 for Pabna; and 20 September 2016 for Joypurhat. Four field-workers i.e. one SAPPO and three SAAOs experienced and engaged in crop-based data documentation, all officers from all upazilas viz UAOs, AEOs, AAEOs, DD (DAE), DD (Horticulture), DD of Seed Certification Agency, DTO and ADDs, one representative from Agricultural Training Institute (ATI) and scientists of BRRI regional station, Kushtia, and Rangpur, participated in the data validation workshop. The number of participants of validation workshop ranged from 50 to 92 in each district. All the participants were divided into three to four groups for data validation. Each group was facilitated by two RFSD scientists to finalize and validate the data and authenticated data were captured. Crop diversity index was calculated by using the following equation described by Kshirsagar et al. (1997).

$$
C D I_{i}=1-\sum_{j=o}^{n}\left(\frac{a_{i j}}{A_{i}}\right)^{2}
$$

Where, $\mathrm{CDI}_{\mathrm{i}}=$ Crop Diversity Index $a_{i j}=$ Area planted to the $j^{\text {th }}$ crop in the $i^{\text {th }}$ location

$A_{i}=$ Total area planted under all crops 
The index is zero for a land area growing only one crop. It approaches unity as the level of diversity increases. Compilation and processing of collected data were done using Micro Soft Excel programme. Descriptive statistics were used to facilitate the presentation of the findings.

\section{RESULTS AND DISCUSSION}

\section{Land use}

Table 1 presents the status of agricultural land utilization. The net cropped area of the Bogra region is 668,440 ha. Crops occupied the particular land for round the year were considered under annual crops. The major annual crops reported in the region were banana, papaya, sugarcane, betel leaf, ginger and turmeric. The annual crops area in different upazilas ranged from 10 to 3,500 ha. The annual crops area accounted only $1.70 \%$ of the net cropped area (NCA) in the region. At a glance the region possesses $7.58 \%$ single cropped area (SCA), 48.09\% double cropped area (DCA), $41.15 \%$ triple cropped area (TCA). The quadruple cropped area also exists as a very negligible portion $(0.76 \%)$ and was limited in only six upazilas viz Bogra, Dhunat, Nandigram, Sherpur, Sonatola and Atghoria. Most of the upazilas of Bogra and Joypurhat district cropping intensity was very high (246\%-291\%) which were dominating by the TCA over SCA and DCA (Table 1). The TCA had the major share of NCA in Adamdighi, Bogra sadar, Dupchachia, Kahalu, Nandigram, Shibganj and Sonatola upazilas of Bogra district, all five upazilas of Joypurhat district, Iswardi, Pabna sadar and Santhia of Pabna district and Kazipur of Sirajganj district. A few upazilas were dominated by DCA viz-Dhunat, Gabtali, Sariakandi, Sherpur and Shajahanpur of Bogra district. In Pabna district Atghoria, Bera, Bhangura, Chatmohar, Faridpur and Sujanagar upazilas and in Sirajganj district all upzilas except Kazipur were dominated by DCA over SCA and TCA (Table 1). The area which could not defined under SCA, DCA,
TCA or QCA was considered as others whose coverage is less than $1 \%$ of the NCA. For availability of irrigation water in dry season, supply of modern varieties of various crops, skilled technology transfer system, knowledge of modern crop management practices, good communication and marketing facilities helped increasing land use efficiency in a given area (FAO, 1988).

\section{Cropping patterns of Bogra}

In total 177 cropping patterns were observed in Bogra region of which six cropping patterns with exclusive rice crop covers about $34 \%$ of the NCA. There were 55 cropping patterns with exclusive non-rice crop occupying over $12 \%$ of the NCA. Rest of the NCA i.e. about $54 \%$ area is covered by 116 rice - non rice cropping patterns (Appendix 1).

\section{Rice and non-rice crops at a glance}

Table 2 presents six cropping patterns where rice was the only crop round the year. It comprises about $34 \%$ of the NCA in the region. Among them single rice, double rice and triple rice areas represent around $6 \%, 25 \%$ and $3 \%$ respectively. It reflects the unparallel dominance of rice in the cropping systems in Bogra region. In case of individual pattern, Boro-Fallow-T. Aman has the highest coverage (approx. 22\%) and was recorded in 27 upazilas out of 35 . The second dominant pattern single Boro area occupied $5.68 \%$ of NCA which was reported in 21 upazilas. Boro-Aus-T. Aman covered 3\% of NCA and was obsrved in 15 upazilas. Single T. Aman area was very negligible $(0.23 \%)$ with its existence in only two upazilas.

In the current investigation, 55 cropping patterns were identified that was free from rice. Among these 55 patterns first 40 have been arranged in descending order in Table 3. The rest 15 patterns with negligible area coverage (Table 9) where they are arranged with other patterns of different categories. Aggregate of the 55 patterns have engaged 82,815 hectares of land, which is equivalent to more than $12 \%$ of NCA in the region. In critical comparison it is clear that exclusive rice area is about three 
Table 1. Land use of different upazilas in Bogra region (area in hectare), 2014-15.

\begin{tabular}{|c|c|c|c|c|c|c|c|c|c|c|}
\hline & Upazila & $\begin{array}{l}\text { Area of } \\
\text { upazila }\end{array}$ & $\begin{array}{r}\text { Annual } \\
\text { crop }\end{array}$ & SCA & DCA & TCA & QCA & Other & NCA & C.I. (\%) \\
\hline 01 & Adamdighi & 16890 & 40 & 200 & 4450 & 7920 & 0 & 130 & 12740 & 261 \\
\hline 02 & Bogra & 17734 & 150 & 0 & 1940 & 8700 & 300 & 110 & 11200 & 282 \\
\hline 03 & Dhunat & 24712 & 50 & 920 & 14750 & 3570 & 150 & 100 & 19540 & 215 \\
\hline 04 & Dubchachia & 16426 & 30 & 0 & 3090 & 10490 & 0 & 110 & 13720 & 277 \\
\hline 05 & Gabtali & 24375 & 120 & 1210 & 12980 & 4710 & 0 & 140 & 19160 & 218 \\
\hline 07 & Nandigram & 26551 & 10 & 0 & 9000 & 9500 & 3700 & 100 & 22310 & 276 \\
\hline 08 & Sariakandi & 40858 & 40 & 3700 & 15620 & 4850 & 0 & 130 & 24340 & 205 \\
\hline 09 & Sherpur & 29640 & 130 & 1490 & 15010 & 6390 & 790 & 130 & 16040 & 227 \\
\hline 10 & Shibganj & 31148 & 150 & 0 & 3360 & 21960 & 0 & 120 & 23950 & 282 \\
\hline 11 & Shajahanpur & 22108 & 620 & 630 & 7860 & 7290 & 0 & 130 & 26070 & 241 \\
\hline 15 & Kalai & 16636 & 10 & 0 & 1485 & 12280 & 0 & 135 & 13910 & 289 \\
\hline 16 & Khetlal & 14260 & 30 & 10 & 1010 & 10490 & 0 & 140 & 11680 & 291 \\
\hline 17 & Panchbibi & 27853 & 570 & 0 & 9800 & 12100 & 0 & 200 & 22670 & 251 \\
\hline 18 & Atghoria & 18380 & 220 & 800 & 6710 & 6130 & 30 & 130 & 14020 & 237 \\
\hline 19 & Bera & 24871 & 700 & 3540 & 12330 & 1250 & 0 & 180 & 18000 & 183 \\
\hline 20 & Bhangura & 13428 & 80 & 2170 & 6890 & 1780 & 0 & 160 & 11080 & 196 \\
\hline 21 & Chatmohar & 29405 & 120 & 1150 & 17950 & 5700 & 0 & 150 & 25070 & 218 \\
\hline 22 & Faridpur & 13897 & 40 & 1000 & 9350 & 1000 & 0 & 150 & 11540 & 200 \\
\hline 23 & Iswardi & 26947 & 3500 & 30 & 2590 & 12530 & 0 & 150 & 18800 & 247 \\
\hline 24 & Pabna sadar & 44259 & 700 & 1580 & 11000 & 22200 & 0 & 120 & 35600 & 256 \\
\hline 31 & Raiganj & 26667 & 400 & 1100 & 17880 & 2300 & 0 & 120 & 21800 & 203 \\
\hline 32 & Shahjadpur & 32462 & 10 & 1870 & 16900 & 6000 & 0 & 120 & 24900 & 217 \\
\hline 33 & Sirajganj & 30855 & 1500 & 1240 & 16550 & 4220 & 0 & 190 & 23700 & 206 \\
\hline 34 & Tarash & 29732 & 10 & 3675 & 17635 & 3305 & 0 & 125 & 24750 & 198 \\
\hline \multirow[t]{2}{*}{35} & Ullapara & 41461 & 40 & 5440 & 18070 & 8390 & 0 & 150 & 32090 & 209 \\
\hline & Bogra region & & 11380 & 50655 & 321460 & 275030 & 5100 & 4815 & 668440 & 234 \\
\hline
\end{tabular}

SCA-Single cropped area, DCA-Double cropped area, TCA-Triple cropped are, QCA-Quadruple cropped area, NCA-Net cropped area and C.I.-Cropping Intensity.

Table 2. Cropping patterns with exclusive rice in Bogra region, 2014-15.

\begin{tabular}{llrrr}
\hline & Cropping pattern & Area (ha) & \% of NCA & Frequency (no. of upazila) \\
\hline 01 & Boro-Fallow-T. Aman & 146250 & 21.87 & 27 \\
02 & Boro-Fallow-Fallow & 37300 & 5.58 & 21 \\
03 & Boro-Aus-T. Aman & 19700 & 2.95 & 15 \\
04 & Boro-B. Aman & 18650 & 2.79 & 10 \\
05 & Fallow-Fallow-T. Aman & 1550 & 0.23 & 2 \\
06 & Boro-Aus-Fallow & 670 & 0.10 & 3 \\
\hline & Total area for exclusive rice & 225000 & 33.66 & - \\
\hline
\end{tabular}

NCA-Net cropped area.

76 Islam et al 
Table 3. Cropping patterns with exclusive non-rice in Bogra region, 2014-15.

\begin{tabular}{|c|c|c|c|c|}
\hline & Cropping pattern & Area (ha) & $\%$ of NCA & Frequency (no. of upazila) \\
\hline 01 & Vegetab-Vegetab-Vegetab & 16030 & 2.40 & 22 \\
\hline 02 & Onion-Jute-Fallow & 10080 & 1.51 & 5 \\
\hline 03 & Lentil-Jute-Fallow & 6650 & 0.99 & 10 \\
\hline 04 & Chilli-Jute-Fallow & 4620 & 0.69 & 10 \\
\hline 05 & Groundnut-Fallow-Fallow & 4280 & 0.64 & 9 \\
\hline 06 & Wheat-Jute-Fallow & 4090 & 0.61 & 11 \\
\hline 07 & Vegetab-Vegetab-Fallow & 3730 & 0.56 & 10 \\
\hline 08 & Maize-Jute-Fallow & 3300 & 0.49 & 6 \\
\hline 09 & Onion-Vegtab-Vegetab & 3100 & 0.46 & 14 \\
\hline 10 & Maize-Fallow-Fallow & 2520 & 0.38 & 5 \\
\hline 11 & Wheat-Vegetab-Vegetab & 2100 & 0.31 & 3 \\
\hline 12 & Millet (kaon)+Sesame-Fallow & 1720 & 0.26 & 4 \\
\hline 13 & Chilli-Vegetab-Fallow & 1650 & 0.25 & 10 \\
\hline 14 & Potato-Maize-Vegetab & 1500 & 0.22 & 1 \\
\hline 15 & Vegetab-Jute-Fallow & 1240 & 0.19 & 4 \\
\hline 16 & Fallow-Fallow-Blackgram & 1210 & 0.18 & 6 \\
\hline 17 & Grasspea-Fallow-Fallow & 1005 & 0.15 & 3 \\
\hline 18 & Vegetab-Onion-Aus & 1000 & 0.15 & 1 \\
\hline 19 & Wheat-Sesame-Fallow & 1000 & 0.15 & 3 \\
\hline 20 & Vegetab-Fallow-Fallow & 900 & 0.13 & 3 \\
\hline 21 & Wheat-Fallow-Blackgram & 900 & 0.13 & 1 \\
\hline 22 & Lentil-Sesame-Fallow & 810 & 0.12 & 4 \\
\hline 23 & Groundnut-Fallow-Blackgram & 800 & 0.12 & 1 \\
\hline 24 & S.Potato-Jute-Fallow & 780 & 0.12 & 3 \\
\hline 25 & Chilli-Fallow-Fallow & 710 & 0.11 & 4 \\
\hline 26 & S.Potato-Fallow-Fallow & 675 & 0.10 & 14 \\
\hline 27 & Coriander-Vegetab-Fallow & 630 & 0.09 & 2 \\
\hline 28 & Grasspea-Jute-Fallow & 550 & 0.08 & 3 \\
\hline 29 & Sesame-Fallow-Blackgram & 500 & 0.07 & 1 \\
\hline 30 & Wheat-Jute-Blackgram & 500 & 0.07 & 1 \\
\hline 31 & Garlic-Jute-Fallow & 430 & 0.06 & 2 \\
\hline 32 & Grasspea-Sesbania-Fallow & 400 & 0.06 & 1 \\
\hline 33 & Groundnut-Millet (kaon)-Fallow & 380 & 0.06 & 2 \\
\hline 34 & Vegetab-Jute-Vegetab & 380 & 0.06 & 1 \\
\hline 35 & Onion-Sesame-Fallow & 350 & 0.05 & 2 \\
\hline 36 & Garlic-Vegetab-Vegetab & 345 & 0.05 & 9 \\
\hline 37 & Groundnut-Sesame-Fallow & 300 & 0.04 & 1 \\
\hline 38 & Lentil-Vegetab-Vegetab & 270 & 0.04 & 5 \\
\hline 39 & Wheat-Fallow-Fallow & 230 & 0.03 & 1 \\
\hline 40 & Vegetab-Fallow-Blackgram & 200 & 0.03 & 3 \\
\hline \multirow[t]{2}{*}{$41-55$} & Other 15 patterns (in Table 9) & 950 & 0.14 & - \\
\hline & Total area for non-rice exclusive & 82815 & 12.39 & \\
\hline
\end{tabular}

folds of exclusive non-rice area. In Bogra region crop diversity is much wider than that of other regions like Sylhet and Chittagong where exclusive rice area covers 37 folds and 23 folds, respectively of exclusive non-rice area (Muttaleb et al., 2017; Shahidullah et al., 2017). Appropriate cropping patterns may facilitate maximum possible land utilization as well as efficient use of other scarce resources in a sustainable manner. Diversified cropping 
pattern may be an option for the farmers as a coping strategy against risks (Mandal and Bezbaruah, 2013). Typology of different cropping systems is the base for the managers of these systems to intensify production (Shriar, 2000).

\section{Deep water rice}

Table 4 presents deep water rice dominating 21 patterns which intogether covered $9.48 \%$ of NCA. Among thm, first 18 patterns cover 63,160 ha whereas other three minutely distributed patterns cover only 220 ha (Table 9). Boro-B. Aman cropping pattern covers the highest area of 18,650 hectares which represents about $2.79 \%$ of the regions NCA. This pattern is distributed over 10 upazilas out of 35. The second highest Wheat-B. Aman cropping pattern covers 7,920 hectares and distributed over only six upazilas. Grasspea-B. Aman is the third dominant cropping pattern under deep water ecosystem which is distributed over the highest number of upazilas. Deep water rice with lentil, maize, pea and grass pea were the narrow existence covered only $0.3 \%$ of NCA. The water level of this ecosystem ranges between 150 and 400 $\mathrm{cm}$, and water usually remains 3-4 months. Special rice varieties known as 'floating rice' are planted in these areas. In the past Bangladesh had had a land coverage of 3 million hectares for deepwater rice (Jackson et al., 1972). In course of time the continuous effort on modern agriculture shifted DWR area mainly to modern Boro. Now the area under deep water rice in Bangladesh is reduced to 0.4 million hectares (Nasim et al., 2017). Though this cropping system is less productive than other modern cropping systems, however, the specific fragile ecosystem still struggling because of no other alternatives.

\section{Non-rice cereal crops}

There were forty-three cropping patterns recorded in Table 5. In these patterns wheat and maize were major crops whereas barley and millets (cheena and kaon) were recognized as minor crops. Wheat-Jute-T. Aman was the most dominant pattern which possessed $2.18 \%$ of NCA and reported in 24 upazilas out of 35 .
In this documentation the aggregate of nonrice cereal cropping patterns covered 9.61\% of NCA. The total area coverage under nonrice cereal crops is 64,475 ha where the first 31 patterns presented in the Table 5 covered 63,730 ha. The remaining 12 patterns are scatteredly distributed over the region which is presented in Table 9. The area coverage of these 12 patterns is only 745 ha which is about $0.11 \%$ of the net cropped area.

\section{Oil-seed crops}

Table 6 presents 31 cropping patterns of oil seed crops. Among the patterns the first 34 patterns possessed 135,700 ha whereas other five patterns covered only 385 ha (Table 9). Mustard is covering the largest area whereas groundnut is cultivated in the smallest area among the oil-seed crops. The mustard crop alone was leading 15 cropping patterns with an area coverage of 111,050 ha which is equivalent to $16.61 \%$ of NCA in the region and it is fourfifths of the total oil-seed crop area. MustardBoro-T. Aman is a favorite cropping pattern reported in 25 upazilas in this region and the area coverage is about $6.00 \%$ of NCA although the highest area coverage among the oil-seed crops is covered by Mustard-Boro-Fallow cropping pattern $(7.62 \%$ of NCA).

\section{Pulse crops}

In total 41 cropping patterns of the pulse crops are enlisted in the Table 7. Among them grasspea was covering the largest area $(17,445$ ha) whereas pea is cultivated in the smallest area (680 ha). Lentil-Jute-Fallow was the dominant cropping pattern in respect of area coverage under pulse crop in the region on the other hand Gasspea-B. Aman was the most widely distributed pulse crop pattern over the region (Table 7 ). The total area coverage of pulse crop is about 49,585 hectares of which 34 patterns listed in the Table 7 covered 48,880 ha area. The remaining 705 ha area is covered by other seven patterns which are presented in the Table 9. In case of pea there are only two cropping patterns viz Pea-B. Aman and Pea-Aus-Vegetable. These two patterns in-together occupied only $0.1 \%$ of NCA. In the documentation of pulse 
Table 4. Cropping patterns under deep water rice ecosystem in Bogra region, 2014-15.

\begin{tabular}{lccc}
\hline Cropping pattern & Area (ha) & \% of NCA & Frequency (no. of upazila) \\
\hline 01 Boro-B. Aman & 18650 & 2.79 & 10 \\
02 Wheat-B. Aman & 7920 & 1.18 & 6 \\
03 Grasspea-B. Aman & 6470 & 0.97 & 12 \\
04 Mustard-Boro-B. Aman & 5000 & 0.75 & 4 \\
05 Onion-B. Aman & 3650 & 0.55 & 7 \\
06 Garlic-B. Aman & 3100 & 0.46 & 4 \\
07 Blackgram-B. Aman & 2950 & 0.44 & 5 \\
08 Grasspea-Boro-B. Aman & 2600 & 0.39 & 2 \\
09 Mustard-B. Aman & 2300 & 0.34 & 3 \\
10 Blackgram (Fod)-Boro-B. Aman & 2000 & 0.30 & 1 \\
11 Onion-Sesame+B. Aman & 1800 & 0.27 & 2 \\
12 Grasspea-Sesame+B. Aman & 1700 & 0.25 & 1 \\
13 Fallow-Sesame+B. Aman & 1400 & 0.21 & 2 \\
14 Lentil-Sesame+B. Aman & 980 & 0.15 & 1 \\
15 Mustard-B. Aus+B. Aman & 800 & 0.12 & 1 \\
16 Lentil-B. Aman & 790 & 0.12 & 4 \\
17 Maize-B. Aman & 650 & 0.10 & 2 \\
18 Pea-B. Aman & 400 & 0.06 & - \\
19-21 Other three patterns (in Table 9) & 220 & 0.03 & \\
\hline Total DW rice & 63380 & 9.48 & \\
\hline
\end{tabular}

Table 5. Cropping patterns for non-rice cereal crops in Bogra region, 2014-15.

\begin{tabular}{|c|c|c|c|}
\hline Cropping pattern & Area (ha) & $\%$ of NCA & Frequency (no. of upazila) \\
\hline 01 Wheat-Jute-T. Aman & 14540 & 2.18 & 24 \\
\hline 02 Wheat-B. Aman & 7920 & 1.18 & 6 \\
\hline 03 Wheat-Aus-Fallow & 4700 & 0.70 & 2 \\
\hline 04 Wheat-Jute-Fallow & 4090 & 0.61 & 11 \\
\hline 05 Wheat-Aus-T. Aman & 3630 & 0.54 & 13 \\
\hline 06 Maize-Jute-Fallow & 3300 & 0.49 & 6 \\
\hline 07 Maize-Fallow-Fallow & 2520 & 0.38 & 5 \\
\hline 08 Wheat-Sesame-T. Aman & 2470 & 0.37 & 7 \\
\hline 09 Maize-Jute-T. Aman & 2255 & 0.34 & 4 \\
\hline 10 Wheat-Vegetab-Vegetab & 2100 & 0.31 & 3 \\
\hline 11 Wheat-Mungbean-T. Aman & 1990 & 0.30 & 6 \\
\hline 12 Millet (kaon)+Sesame-Fallow & 1720 & 0.26 & 4 \\
\hline 13 Wheat-Fallow-T. Aman & 1560 & 0.23 & 3 \\
\hline 14 Millet (kaon)-Fallow-T. Aman & 1500 & 0.22 & 1 \\
\hline 15 Potato-Maize-Vegetab & 1500 & 0.22 & 1 \\
\hline 16 Potato-Maize-T. Aman & 1200 & 0.18 & 4 \\
\hline 17 Wheat-Sesame-Fallow & 1000 & 0.15 & 3 \\
\hline 18 Wheat-Fallow-Blackgram & 900 & 0.13 & 1 \\
\hline 19 Wheat-Maize-T. Aman & 700 & 0.10 & 1 \\
\hline 20 Maize-B. Aman & 650 & 0.10 & 2 \\
\hline 21 Maize-Fallow-T. Aman & 640 & 0.10 & 5 \\
\hline 22 Wheat-Jute-Blackgram & 500 & 0.07 & 1 \\
\hline 23 Groundnut-Millet (kaon)-Fallow & 380 & 0.06 & 2 \\
\hline 24 Maize-Maize-T. Aman & 330 & 0.05 & 4 \\
\hline 25 Maize-Aus-Fallow & 320 & 0.05 & 3 \\
\hline 26 Maize-Sesame-T. Aman & 300 & 0.04 & 1 \\
\hline 27 Potato-Maize-Aus & 300 & 0.04 & 1 \\
\hline 28 Potato-Maize-Aus-Vegetab & 300 & 0.04 & 1 \\
\hline 29 Wheat-Fallow-Fallow & 230 & 0.03 & 1 \\
\hline 30 Millet (cheena)-Jute-Fallow & 170 & 0.03 & 1 \\
\hline 31 Barley-Fallow-Fallow & 15 & 0.00 & 2 \\
\hline 32-43 Other 12 patterns (in Table 9) & 745 & 0.11 & - \\
\hline Total for non-rice cereal crops & 64475 & 9.61 & \\
\hline
\end{tabular}


Table 6. Cropping patternsof oil-seed crops in Bogra region, 2014-15.

\begin{tabular}{|c|c|c|c|c|}
\hline & Cropping pattern & Area (ha) & $\%$ of NCA & Frequency (no. of upazila) \\
\hline 01 & Mustard-Boro-Fallow & 50940 & 7.62 & 15 \\
\hline 02 & Mustard-Boro-T. Aman & 40110 & 6.00 & 25 \\
\hline 03 & Mustard-Boro-B. Aman & 5000 & 0.75 & 4 \\
\hline 04 & Groundnut-Fallow-Fallow & 4280 & 0.64 & 9 \\
\hline 05 & Mustard-Jute-T. Aman & 2700 & 0.40 & 3 \\
\hline 06 & Mustard-Boro-Aus & 2560 & 0.38 & 2 \\
\hline 07 & Wheat-Sesame-T. Aman & 2470 & 0.37 & 7 \\
\hline 08 & Mustard-Boro-Aus-T. Aman & 2330 & 0.35 & 4 \\
\hline 09 & Mustard-B. Aman & 2300 & 0.34 & 3 \\
\hline 10 & Mustard-Aus-T. Aman & 2200 & 0.33 & 4 \\
\hline 11 & Onion-Sesame-T. Aman & 2200 & 0.33 & 2 \\
\hline 12 & Onion-Sesame+B. Aman & 1800 & 0.27 & 2 \\
\hline 13 & Millet (kaon)+Sesame-Fallow & 1720 & 0.26 & 4 \\
\hline 14 & Grasspea-Sesame+B. Aman & 1700 & 0.25 & 1 \\
\hline 15 & Lentil-Sesame-T. Aman & 1680 & 0.25 & 6 \\
\hline 16 & Fallow-Sesame+B. Aman & 1400 & 0.21 & 2 \\
\hline 17 & Wheat-Sesame-Fallow & 1000 & 0.15 & 3 \\
\hline 18 & Lentil-Sesame+B. Aman & 980 & 0.15 & 1 \\
\hline 19 & Grasspea-Sesame-T. Aman & 970 & 0.15 & 2 \\
\hline 20 & Lentil-Sesame-Fallow & 810 & 0.12 & 4 \\
\hline 21 & Groundnut-Fallow-Blackgram & 800 & 0.12 & 1 \\
\hline 22 & Mustard-B.Aus+B. Aman & 800 & 0.12 & 1 \\
\hline 23 & Mustard-Boro-Jute & 700 & 0.10 & 1 \\
\hline 24 & Potato-Sesame-T. Aman & 600 & 0.09 & 2 \\
\hline 25 & Groundnut-Jute-T. Aman & 500 & 0.07 & 1 \\
\hline 26 & Sesame-Fallow-Blackgram & 500 & 0.07 & 1 \\
\hline 27 & Mustard-Aus-Blackgram & 400 & 0.06 & 1 \\
\hline 28 & Mustard-Mungbean-T. Aman & 400 & 0.06 & 1 \\
\hline 29 & Groundnut-Millet (kaon)-Fallow & 380 & 0.06 & 2 \\
\hline 30 & Onion-Sesame-Fallow & 350 & 0.05 & 2 \\
\hline 31 & Mustard-Sesame-T. Aman & 320 & 0.05 & 2 \\
\hline 32 & Groundnut-Sesame-Fallow & 300 & 0.04 & 1 \\
\hline 33 & Maize-Sesame-T. Aman & 300 & 0.04 & 1 \\
\hline 34 & Sesame-Aus-Fallow & 200 & 0.03 & 1 \\
\hline \multirow[t]{2}{*}{$35-39$} & Other five patterns (in Table 9) & 385 & 0.06 & - \\
\hline & Total oil-seed crops & 136085 & 20.36 & \\
\hline
\end{tabular}

crop grasspea reported its widest spreading in the region. One pattern is available in 12 out of 35 upazilas. Finally the aggregate area of the pulse crop cropping system stands for $7.42 \%$ of the NCA in Bogra region.

\section{Vegetables and spices crops}

Fifty-three cropping patterns have been arranged in descending order according to area coverage (Table 8). Potato and other vegetables of Rabi, Kharif-I and Kharif-II; spices viz chilli, onion, garlic are included in this list. A row is included at the end of the Table 8 representing an aggregate of 25 patterns of vegetables and spices, which is elaborately presented in the Table 9 with other patterns of different categories. The most contributing cropping pattern is Potato-Boro-T. Aman covering about $13.26 \%$ of NCA, which was distributed over 17 upazilas. Year round vegetable was the second most dominant cropping pattern which possessed 16,030 ha covering $2.40 \%$ of NCA and recorded in 22 upazilas out of 35 . OnionJute-Fallow is the third dominant pattern but exists only in five upazilas. Among the spices onion occupied the major area under 
Table 7. Cropping patterns of pulse crops in Bogra region, 2014-15.

\begin{tabular}{|c|c|c|c|c|}
\hline & Cropping pattern & Area (ha) & $\%$ of NCA & Frequency (no. of upazila) \\
\hline 01 & Lentil-Jute-Fallow & 6650 & 0.99 & 10 \\
\hline 02 & Grasspea-B. Aman & 6470 & 0.97 & 12 \\
\hline 03 & Lentil-Aus-T. Aman & 3340 & 0.50 & 9 \\
\hline 04 & Blackgram-B. Aman & 2950 & 0.44 & 5 \\
\hline 05 & Grasspea-Boro-Fallow & 2950 & 0.44 & 5 \\
\hline 06 & Grasspea-Boro-B. Aman & 2600 & 0.39 & 2 \\
\hline 07 & B.gram(Fodder)-Boro-B. Aman & 2000 & 0.30 & 1 \\
\hline 08 & Wheat-Mungbean-T. Aman & 1990 & 0.30 & 6 \\
\hline 09 & Boro-Fallow-Blackgram & 1960 & 0.29 & 7 \\
\hline 10 & Grasspea-Sesame+B. Aman & 1700 & 0.25 & 1 \\
\hline 11 & Lentil-Sesame-T. Aman & 1680 & 0.25 & 6 \\
\hline 12 & Fallow-Fallow-Blackgram & 1210 & 0.18 & 6 \\
\hline 13 & Grasspea-Fallow-Fallow & 1005 & 0.15 & 3 \\
\hline 14 & Lentil-Sesame+B. Aman & 980 & 0.15 & 1 \\
\hline 15 & Lentil-Jute-T. Aman & 975 & 0.15 & 7 \\
\hline 16 & Grasspea-Sesame-T. Aman & 970 & 0.15 & 2 \\
\hline 17 & Wheat-Fallow-Blackgram & 900 & 0.13 & 1 \\
\hline 18 & Lentil-Sesame-Fallow & 810 & 0.12 & 4 \\
\hline 19 & Grasspea-Jute-T. Aman & 800 & 0.12 & 1 \\
\hline 20 & Groundnut-Fallow-Blackgram & 800 & 0.12 & 1 \\
\hline 21 & Lentil-B. Aman & 790 & 0.12 & 4 \\
\hline 22 & Onion-Aus-Blackgram & 740 & 0.11 & 3 \\
\hline 23 & Grasspea-Jute-Fallow & 550 & 0.08 & 3 \\
\hline 24 & Sesame-Fallow-Blackgram & 500 & 0.07 & 1 \\
\hline 25 & Wheat-Jute-Blackgram & 500 & 0.07 & 1 \\
\hline 26 & Boro-Aus-Blackgram & 410 & 0.06 & 2 \\
\hline 27 & Grasspea-Sesbania-Fallow & 400 & 0.06 & 1 \\
\hline 28 & Mustard-Aus-Blackgram & 400 & 0.06 & 1 \\
\hline 29 & Mustard-Mungbean-T. Aman & 400 & 0.06 & 1 \\
\hline 30 & Pea-B. Aman & 400 & 0.06 & 2 \\
\hline 31 & Lentil-Aus-Fallow & 300 & 0.04 & 3 \\
\hline 32 & Pea-Aus-Vegetab & 280 & 0.04 & 1 \\
\hline 33 & Lentil-Vegetab-Vegetab & 270 & 0.04 & 5 \\
\hline 34 & Vegetab-Fallow-Blackgram & 200 & 0.03 & 3 \\
\hline \multirow[t]{2}{*}{$35-41$} & Other seven patterns (in Table 9) & 705 & 0.11 & \\
\hline & Total pulse crop & 49585 & 7.42 & \\
\hline
\end{tabular}

cultivation. Vegetables like colocasia, okra, amaranths, brinjal, cucurbits, etc are grown in medium upland adjacent to rice fields during rainy season and potato, sweet gourd, cole crops, leafy vegetables etc are grown during winter season in Tripura (Das et al., 2015).

\section{Sporadic and distinct cropping patterns}

There are some cropping patterns which are extremely location-specific, however, with a large area coverage. The Blackgram (fodder)Boro-B. Aman is grown on 2,000 hectares (Table 7) in Shahjadpur upazila of Sirajganj district. It is a unique pattern in Bangladesh. Shahjadpur is the main centre of the milch cattle/cow under the supervision of Milk Vita Cooperative Systems. Now-a-days other NGO and private enterprises are also going there for milk collection. For feeding these cattle the farmers of the locality has adopted this cropping system. In this system blackgram is grown as relay crop where the seeds of blackgram are broadcast in the standing deepwater rice at flowering stage. After harvesting of rice, blackgram is rapidly grown and are subjected to cattle feeding at green stage. Grasspea- 
Table 8. Cropping patterns for vegetables and spices crops in Bogra region, 2014-15.

\begin{tabular}{|c|c|c|c|c|}
\hline & Cropping pattern & Area (ha) & $\%$ of NCA & Frequency (no. of upazila) \\
\hline 01 & Potato-Boro-T. Aman & 88610 & 13.26 & 17 \\
\hline 02 & Vegetab-Vegetab-Vegetab* & 16030 & 2.40 & 22 \\
\hline 03 & Onion-Jute-Fallow & 10080 & 1.51 & 5 \\
\hline 04 & Onion-Jute-T. Aman & 9330 & 1.40 & 12 \\
\hline 05 & Vegetab-Boro-T. Aman & 4760 & 0.71 & 7 \\
\hline 06 & Chilli-Jute-Fallow & 4620 & 0.69 & 10 \\
\hline 07 & Boro-Vegetab(Float/Norm**) & 4000 & 0.60 & 6 \\
\hline 08 & Vegetab-Vegetab-Fallow & 3730 & 0.56 & 10 \\
\hline 09 & Onion-B. Aman & 3650 & 0.55 & 7 \\
\hline 10 & Garlic-B. Aman & 3100 & 0.46 & 4 \\
\hline 11 & Onion-Vegtab-Vegetab & 3100 & 0.46 & 14 \\
\hline 12 & Chilli-Jute-T. Aman & 2300 & 0.34 & 2 \\
\hline 13 & Potato-Boro-Aus-T. Aman & 2250 & 0.34 & 2 \\
\hline 14 & Onion-Sesame-T. Aman & 2200 & 0.33 & 2 \\
\hline 15 & Wheat-Vegetab-Vegetab & 2100 & 0.31 & 3 \\
\hline 16 & Vegetab-Aus-Fallow & 2060 & 0.31 & 5 \\
\hline 17 & Onion-Aus-T. Aman & 1910 & 0.29 & 3 \\
\hline 18 & Onion-Sesame+B. Aman & 1800 & 0.27 & 2 \\
\hline 19 & Vegetab-Fallow-T. Aman & 1790 & 0.27 & 6 \\
\hline 20 & Potato-Vegetab-T. Aman & 1670 & 0.25 & 5 \\
\hline 21 & Vegetab-Aus-T. Aman & 1665 & 0.25 & 6 \\
\hline 22 & Chilli-Vegetab-Fallow & 1650 & 0.25 & 10 \\
\hline 23 & Potato-Maize-Vegetab & 1500 & 0.22 & 1 \\
\hline 24 & Potato-Jute-T. Aman & 1280 & 0.19 & 7 \\
\hline 25 & Vegetab-Jute-Fallow & 1240 & 0.19 & 4 \\
\hline 26 & Chilli-Aus-Fallow & 1210 & 0.18 & 4 \\
\hline 27 & Potato-Maize-T. Aman & 1200 & 0.18 & 4 \\
\hline 28 & Vegetab-Vegetab-T. Aman & 1030 & 0.15 & 4 \\
\hline 29 & Garlic-Aus-T. Aman & 1010 & 0.15 & 2 \\
\hline 30 & Vegetab-Onion-Aus & 1000 & 0.15 & 1 \\
\hline 31 & Vegetab-Jute-T. Aman & 980 & 0.15 & 3 \\
\hline 32 & Vegetab-Fallow-Fallow & 900 & 0.13 & 3 \\
\hline 33 & Potato-Boro-Fallow & 750 & 0.11 & 3 \\
\hline 34 & Onion-Aus-Blackgram & 740 & 0.11 & 3 \\
\hline 35 & Chilli-Fallow-Fallow & 710 & 0.11 & 4 \\
\hline 36 & Garlic-Jute-T. Aman & 700 & 0.10 & 6 \\
\hline 37 & Coriander-Vegetab-Fallow & 630 & 0.09 & 2 \\
\hline 38 & Potato-Sesame-T. Aman & 600 & 0.09 & 2 \\
\hline 39 & Chilli-Aus-T. Aman & 430 & 0.06 & 2 \\
\hline 40 & Garlic-Jute-Fallow & 430 & 0.06 & 2 \\
\hline & Garlic-Fallow-T. Aman & 420 & 0.06 & 5 \\
\hline 42 & Vegetab-Jute-Vegetab & 380 & 0.06 & 1 \\
\hline 43 & Onion-Sesame-Fallow & 350 & 0.05 & 2 \\
\hline 44 & Garlic-Vegetab-Vegetab & 345 & 0.05 & 9 \\
\hline 45 & Potato-Boro-Vegetab & 300 & 0.04 & 1 \\
\hline 46 & Potato-Maize-Aus & 300 & 0.04 & 1 \\
\hline 47 & Potato-Maize-Aus-Vegetab & 300 & 0.04 & 1 \\
\hline 48 & Vegetab-Boro-Jute & 300 & 0.04 & 2 \\
\hline 49 & Pea-Aus-Vegetab & 280 & 0.04 & 1 \\
\hline 50 & Lentil-Vegetab-Vegetab & 270 & 0.04 & 5 \\
\hline 51 & Boro-Vegetab-T. Aman & 200 & 0.03 & 2 \\
\hline 52 & Potato-Fallow-T. Aman & 200 & 0.03 & 1 \\
\hline 53 & Vegetab-Fallow-Blackgram & 200 & 0.03 & 3 \\
\hline $54-78$ & Other 25 patterns (in Table 9) & 1485 & 0.22 & - \\
\hline & Total vegetab and spices & 194075 & 29.03 & \\
\hline
\end{tabular}


Table 9. Rare cropping patterns covering non-significant area in Bogra region, 2014-15.

\begin{tabular}{|c|c|c|c|c|c|}
\hline & Cropping pattern & Area (ha) & $\%$ of NCA & Frequency & Upazila \\
\hline 01 & Mustard-Maize-T. Aman & 190 & 0.03 & 1 & Sherpur \\
\hline 02 & Potato-Aus-T. Aman & 180 & 0.03 & 2 & Shahjahanpur+Pabna sadar \\
\hline 03 & Blackgram-Jute-Fallow & 170 & 0.03 & 2 & Sonatola+Kazipur \\
\hline 04 & Millet(cheena)-Jute-Fallow & 170 & 0.03 & 1 & Sariakandi \\
\hline 05 & Vegetab-Boro-Fallow & 170 & 0.03 & 1 & Chowhali \\
\hline 06 & Grasspea-B.Aus+B. Aman & 160 & 0.02 & 2 & Kazipur+Sirajganj sadar \\
\hline 07 & Coriander-Fallow-Fallow & 150 & 0.02 & 2 & Bhangura+Chowhali \\
\hline 08 & S.Potato-Fallow-T. Aman & 115 & 0.02 & 3 & Kalai+Khetlal+Kazipara \\
\hline 09 & Wheat-Mungbean-Fallow & 105 & 0.02 & 2 & Pabna sadar+Tarash \\
\hline 10 & Lentil-Mungbean-T. Aman & 100 & 0.02 & 1 & Pabna sadar \\
\hline 11 & Maize-Aus-T. Aman & 100 & 0.02 & 2 & Shajahanpur+Pabna sadar \\
\hline 12 & Mustard-Boro-Jute-T. Aman & 100 & 0.02 & 1 & Sonatola \\
\hline 13 & Potato-Boro-Jute-T. Aman & 90 & 0.01 & 1 & Sherpur \\
\hline 14 & Onion-Fallow-T. Aman & 80 & 0.01 & 2 & Dubchachia+Khetlal \\
\hline 15 & Pea-Fallow-T. Aman & 80 & 0.01 & 1 & Chowhali \\
\hline 16 & Vegetab-Maize-T. Aman & 80 & 0.01 & 2 & Shajahanpur+Tarash \\
\hline 17 & Maize-Vegetab-T. Aman & 70 & 0.01 & 1 & Shajahanpur \\
\hline 18 & Onion-Aus-Fallow & 70 & 0.01 & 2 & Adamdighi+Kazipur \\
\hline 19 & Onion-Maize-T. Aman & 70 & 0.01 & 1 & Sherpur \\
\hline 20 & Potato-S.gourd-Aus & 70 & 0.01 & 2 & Gabtali+Akkelpur \\
\hline 21 & Garlic-Fallow-Fallow & 60 & 0.01 & 1 & Dhunat \\
\hline 22 & Coriander-Sesame-T. Aman & 55 & 0.01 & 2 & Pabna+Tarash \\
\hline 23 & Blackgram-Aus-T. Aman & 50 & 0.01 & 1 & Sherpur \\
\hline 24 & S.Potato-Vegetab-Fallow & 50 & 0.01 & 1 & Bogra sadar \\
\hline 25 & Blackcumin-Jute-Fallow & 40 & 0.01 & 1 & Chowhali \\
\hline 26 & Chilli-Vegetab-T. Aman & 40 & 0.01 & 1 & Dubchachia \\
\hline 27 & Grasspea-Aus-T. Aman & 40 & 0.01 & 1 & Atghoria \\
\hline 28 & Maize-Maize-Fallow & 40 & 0.01 & 1 & Shajahanpur \\
\hline 29 & Muskmelon-Fallow-Fallow & 40 & 0.01 & 1 & Sirajganj sadar \\
\hline 30 & Chilli-B. Aman & 30 & 0.00 & 1 & Bera \\
\hline 31 & Coriander-Jute-Fallow & 30 & 0.00 & 1 & Kazipur \\
\hline 32 & Garlic-Aus-Fallow & 30 & 0.00 & 1 & Adamdighi \\
\hline 33 & Maize-Sesame-Fallow & 30 & 0.00 & 1 & Tarash \\
\hline 34 & Potato+S.gourd-Aus-T. Aman & 30 & 0.00 & 1 & Sonatola \\
\hline 35 & W.Melon-B. Aman & 30 & 0.00 & 1 & Tarash \\
\hline 36 & Blackcumin-Jute-T. Aman & 20 & 0.00 & 1 & Kazipur \\
\hline 37 & Maize-Vegetab-Fallow & 20 & 0.00 & 1 & Shibganj \\
\hline 38 & Potato-Maize-Fallow & 20 & 0.00 & 1 & Sirajganj sadar \\
\hline 39 & Barley-Fallow-Fallow & 15 & 0.00 & 2 & Chowhali+Tarash \\
\hline 40 & Chilli-Fallow-T. Aman & 10 & 0.00 & 1 & Kalai \\
\hline 41 & Fallow-Sesame-T. Aman & 10 & 0.00 & 1 & Sherpur \\
\hline 42 & Millet(cheena)-Fallow-Fallow & 10 & 0.00 & 1 & Sonatola \\
\hline 43 & Potato-Onion-T. Aman & 10 & 0.00 & 1 & Khetlal \\
\hline 44 & Wheat-Vegetab-T. Aman & 10 & 0.00 & 1 & Khetlal \\
\hline \multirow[t]{2}{*}{45} & S.Potato-Jute-T. Aman & 5 & 0.00 & 1 & Akkelpur \\
\hline & Total & 3045 & 0.46 & & \\
\hline
\end{tabular}


Sesame+B. Aman is grown on 1,700 hectares in Chowhali upazila of the same district. Millet (kaon)-Fallow-T. Aman is cultivated on 1,500 hectares only in Sariakandi of Bogra district. The millet is a small grain cereal crop, which stands on the bank of extinction for its low yield and less economic value, although it is a very nutritious food. Only some marginal land like charland is used for its cultivation (FAO, 1988).

\section{Rare cropping patterns}

In the present investigation, 45 cropping patterns have been identified as rare cropping patterns with negligible area coverage with seldom existence (Table 9). These are location specific system and are limited in one or two upazilas of the region. Total area coverage of the 45 patterns is far less than $1 \%$ of NC Among them the highest area was allotted for MustardMaize-T. Aman (190 ha) and it is recorded only in Sherpur upazila of Bogra district. The smallest area was recorded for S.Potato-Jute-T. Aman cropping patterns whose coverage was only five hectares (Table 9) and is recorded only in Akkelpur upazila of Joypurhat district.

\section{Most dominant cropping pattern}

Boro-Fallow-T. Aman was the most dominant cropping pattern in Bogra region. It covers $21.88 \%$ of NCA in the region and is available in 27 upazilas out of 35 (Table 10). The highest area under this cropping was recorded 16,500 hectares in Raiganj upazila of Sirajganj district which represents $11.28 \%$ of the total Boro-Fallow-T. Aman area of the region. In consideration of indivdual upazila it also covered the highest area and it is $77.10 \%$ of its NCA for this pattern alone. Chatmohar and Bhangura upazila of Pabna district had negligible area coverage for this pattern. In some portion of the double rice area some short duration Rabi crops can be grown before Boro transplanting if appropriate varieties and other related technologies are made available (FAO, 1988). In the country-wide compilation of data it was observed that Boro-F-T. Aman was the most dominant cropping pattern in Bangladesh covering 2.31 million ha $(27 \%$ of NCA in the country) with its distribution in 426 upazilas of 63 districts (Nasim et al., 2017).

\section{Second dominant cropping pattern}

The second dominant cropping pattern in Bogra region is Potato-Boro-T. Aman. It belongs to $13.26 \%$ of NCA of the region and spread over 17 upazilas (Table 11). Shibganj upazila of Bogra district holds the highest area coverage $(18,200$ ha) under this cropping pattern. Kalai upazila ranks in second position in terms of area coverage (11,800 ha) however this upazila allotted the biggest share $(84.83 \%)$ of the upazila NCA. In the country-wide compilation of data it was observed that Potato-Boro-T. Aman was the $8^{\text {th }}$ dominant cropping pattern in Bangladesh covering 1.80 lac ha $(2.11 \%$ of NCA in the country) with its distribution in 115 upazilas of 33 districts (Nasim et al., 2017).

\section{Third dominant cropping pattern}

Mustard-Boro-Fallow cropping pattern holds the third largest area coverage 50,940 hectares in Bogra region. This area is an equivalent to $7.62 \%$ of NCA in the region. This pattern Mustard-Boro-Fallow is distributed over only 15 upazilas. Shahjadpur and Ullapara upazila have the highest area coverage under this pattern and it is 13,000 ha for both the upazilas which stands for $25.52 \%$ of the total area under this pattern in the region for both the locations (Table 12). Belkuchi upazila ranks in third position for this cropping pattern, however, Panchbibi, Santhia and Kazipur covers a minute area of 200 ha for each upazila.

\section{Fourth dominant cropping pattern}

Fourth dominant cropping pattern MustardBoro-T. Aman has occupied 40,110 hectares representing $6.0 \%$ share of NCA in Bogra region (Table 13). This pattern is distributed over 25 upazilas where Kahalu ranked in top position. This upazila has 4,800 ha area of Mustard-Boro-T. Aman which is $24.96 \%$ of upazila NCA. Dupchachia upazila ranks in third position with 3,700 ha area for this pattern; however, this upazila has allotted the biggest share $(26.94 \%)$ of its NCA.

\section{Fifth dominant cropping pattern}

Fifth dominant cropping pattern Boro-FallowFallow had been covering 37,300 hectares 
Table 10. Distribution of the most dominant Boro-F-T. Aman cropping patterns in Bogra region, 2014-15.

\begin{tabular}{|c|c|c|c|c|}
\hline & Upazila & Area (ha) & $\%$ of upazila NCA & $\%$ of the pattern in region \\
\hline 01 & Raiganj & 16500 & 77.10 & 11.28 \\
\hline 02 & Sherpur & 13600 & 57.14 & 9.30 \\
\hline 03 & Dhunat & 13100 & 67.18 & 8.96 \\
\hline 04 & Gabtali & 11500 & 60.37 & 7.86 \\
\hline 05 & Sirajganj sadar & 9000 & 40.54 & 6.15 \\
\hline 06 & Tarash & 8700 & 35.15 & 5.95 \\
\hline 07 & Nandigram & 8000 & 35.87 & 5.47 \\
\hline 08 & Sariakandi & 8000 & 32.92 & 5.47 \\
\hline 09 & Panchbibi & 7900 & 35.75 & 5.40 \\
\hline 10 & Shajahanpur & 6500 & 40.88 & 4.44 \\
\hline 11 & Joypurhat sadar & 5700 & 30.65 & 3.90 \\
\hline 12 & Kahalu & 4700 & 24.48 & 3.21 \\
\hline 13 & Sonatola & 4700 & 34.31 & 3.21 \\
\hline 14 & Atghoria & 4500 & 32.61 & 3.08 \\
\hline 15 & Adamdighi & 4100 & 32.28 & 2.80 \\
\hline 16 & Akkelpur & 3900 & 36.28 & 2.67 \\
\hline 17 & Kazipur & 3200 & 14.16 & 2.19 \\
\hline 18 & Dubchachia & 3000 & 21.90 & 2.05 \\
\hline 19 & Iswardi & 2000 & 13.07 & 1.37 \\
\hline 20 & Bogra sadar & 1800 & 16.29 & 1.23 \\
\hline 21 & Sujanagar & 1800 & 7.38 & 1.23 \\
\hline 22 & Kalai & 1400 & 10.07 & 0.96 \\
\hline 23 & Shibganj & 1200 & 4.72 & 0.82 \\
\hline 24 & Kamarkhanda & 800 & 10.53 & 0.55 \\
\hline 25 & Khetlal & 300 & 2.58 & 0.21 \\
\hline 26 & Chatmohar & 200 & 0.80 & 0.14 \\
\hline \multirow[t]{2}{*}{27} & Bhangura & 150 & 1.36 & 0.10 \\
\hline & Bogra region & 146250 & 21.88 & 100.00 \\
\hline
\end{tabular}

Table 11. Distribution of the $2^{\text {nd }}$ dominant Potato-Boro-T. Aman cropping pattern in Bogra region, $2014-15$.

\begin{tabular}{llrrr}
\hline & Upazila & Area (ha) & \% of upazila NCA & \% of the pattern in region \\
\hline 01 & Shibganj & 18200 & 75.99 & 20.54 \\
02 & Kalai & 11800 & 84.83 & 13.32 \\
03 & Khetlal & 8900 & 76.20 & 10.04 \\
04 & Kahalu & 8600 & 44.72 & 9.71 \\
05 & Dubchachia & 6600 & 48.05 & 7.45 \\
06 & Pachbibi & 6100 & 26.90 & 6.88 \\
07 & Bogra sadar & 6000 & 53.56 & 6.77 \\
08 & Joypurhat sadar & 5500 & 28.35 & 6.21 \\
09 & Akkelpur & 5000 & 46.12 & 5.64 \\
10 & Shajahanpur & 4000 & 16.98 & 4.51 \\
11 & Adamdighi & 3300 & 25.90 & 3.72 \\
12 & Sonatola & 2300 & 16.61 & 2.60 \\
13 & Gabtali & 1300 & 6.78 & 1.47 \\
14 & Sherpur & 360 & 1.38 & 0.41 \\
15 & Ullapara & 250 & 0.78 & 0.28 \\
16 & Kamarkhanda & 200 & 2.59 & 0.23 \\
17 & Tarash & 200 & 0.81 & 0.23 \\
\hline
\end{tabular}


Table 12. Distribution of the $3^{\text {rd }}$ dominant Mustard- Boro-Fallow cropping pattern in Bogra region, 2014-15.

\begin{tabular}{|c|c|c|c|c|}
\hline & Upazila & Area (ha) & $\%$ of upazila NCA & $\%$ of the pattern in region \\
\hline 01 & Shahjadpur & 13000 & 52.20 & 25.52 \\
\hline 02 & Ullapara & 13000 & 40.51 & 25.52 \\
\hline 03 & Belkuchi & 6000 & 46.33 & 11.78 \\
\hline 04 & Tarash & 5100 & 20.60 & 10.01 \\
\hline 05 & Chatmohar & 4000 & 15.96 & 7.85 \\
\hline 06 & Faridpur & 4000 & 34.64 & 7.85 \\
\hline 07 & Bera & 1400 & 7.80 & 2.75 \\
\hline 08 & Bhangura & 1100 & 9.92 & 2.16 \\
\hline 09 & Raiganj & 800 & 3.66 & 1.57 \\
\hline 10 & Gabtali & 740 & 3.86 & 1.45 \\
\hline 11 & Sujanagar & 700 & 2.84 & 1.37 \\
\hline 12 & Sirajganj & 500 & 2.11 & 0.98 \\
\hline 13 & Panchbibi & 200 & 0.88 & 0.39 \\
\hline 14 & Santhia & 200 & 0.79 & 0.39 \\
\hline \multirow[t]{2}{*}{15} & Kazipur & 200 & 0.87 & 0.39 \\
\hline & Bogra region & 50940 & 7.62 & 100.00 \\
\hline
\end{tabular}

Table 13. Distribution of the $4^{\text {th }}$ dominant Mustard-Boro-T. Aman cropping pattern in Bogra region, 2014-15.

\begin{tabular}{|c|c|c|c|c|}
\hline & Upazila & Area (ha) & $\%$ of upazila NCA & $\%$ of the pattern in region \\
\hline 1 & Kahalu & 4800 & 24.96 & 11.97 \\
\hline 2 & Panchbibi & 4200 & 18.52 & 10.47 \\
\hline 3 & Dubchachia & 3700 & 26.94 & 9.22 \\
\hline 4 & Ullapara & 3700 & 11.53 & 9.22 \\
\hline 5 & Adamdighi & 3200 & 25.12 & 7.98 \\
\hline 6 & Joypurhat & 3000 & 15.46 & 7.48 \\
\hline 7 & Dhunat & 2000 & 10.23 & 4.99 \\
\hline 8 & Kamarkhanda & 2000 & 25.86 & 4.99 \\
\hline 9 & Sirajganj & 1600 & 6.74 & 3.99 \\
\hline 10 & Khetlal & 1400 & 11.99 & 3.49 \\
\hline 11 & Sonatola & 1300 & 9.39 & 3.24 \\
\hline 12 & Shariakandi & 1200 & 4.93 & 2.99 \\
\hline 13 & Sherpur & 1100 & 4.67 & 2.74 \\
\hline 14 & Shibganj & 1100 & 4.22 & 2.74 \\
\hline 15 & Akkelpur & 1100 & 10.15 & 2.74 \\
\hline 16 & Belkuchi & 1000 & 7.72 & 2.49 \\
\hline 17 & Raiganj & 900 & 4.11 & 2.24 \\
\hline 18 & Bogra & 800 & 7.14 & 1.99 \\
\hline 19 & Shajahanpur & 600 & 3.74 & 1.50 \\
\hline 20 & Kazipur & 350 & 1.53 & 0.87 \\
\hline 21 & Tarash & 260 & 1.05 & 0.65 \\
\hline 22 & Kalai & 200 & 1.44 & 0.50 \\
\hline 23 & Atghoria & 200 & 1.43 & 0.50 \\
\hline 24 & Bhangura & 200 & 1.80 & 0.50 \\
\hline \multirow[t]{2}{*}{25} & Santhia & 200 & 0.79 & 0.50 \\
\hline & Bogra region & 40110 & 6.00 & 100.00 \\
\hline
\end{tabular}

representing 5.58\% share of NCA in Bogra region (Table 14). This pattern is distributed over 21 upazilas where Kazipur ranked in top position. This upazila had $7,600 \mathrm{ha}$ area for single Boro pattern which is $33.17 \%$ of upazila NCA. Ullapara upazila ranked in second position in respect to area coverage. In the country-wide compilation of data it was observed that the single Boro was the $2^{\text {nd }}$ dominant cropping pattern in Bangladesh covering 1.14 million ha $(13 \%$ of NCA in the country) with its distribution in 342 upazilas of 59 districts (Nasim et al., 2017). This pattern is frequent and concurrently experienced by early flash 
Table 14. Distribution of the $5^{\text {th }}$ dominant Boro-F-F cropping pattern in Bogra region, 2014-15.

\begin{tabular}{|c|c|c|c|c|}
\hline & Upazila & Area (ha) & $\%$ of upazila NCA & $\%$ of the pattern in region \\
\hline 01 & Kazipur & 7600 & 33.17 & 20.38 \\
\hline 02 & Ullapara & 5400 & 16.83 & 14.48 \\
\hline 03 & Tarash & 3000 & 12.12 & 8.04 \\
\hline 04 & Chowhali & 2400 & 18.88 & 6.43 \\
\hline 05 & Bhangura & 2100 & 18.94 & 5.63 \\
\hline 06 & Sariakandi & 2000 & 8.21 & 5.36 \\
\hline 07 & Sujanagar & 1800 & 7.29 & 4.83 \\
\hline 08 & Shahjadpur & 1800 & 7.23 & 4.83 \\
\hline 09 & Pabna & 1500 & 4.21 & 4.02 \\
\hline 10 & Bera & 1400 & 7.80 & 3.75 \\
\hline 11 & Gabtali & 1200 & 6.26 & 3.22 \\
\hline 12 & Sherpur & 1000 & 3.84 & 2.68 \\
\hline 13 & Chatmohar & 1000 & 3.99 & 2.68 \\
\hline 14 & Faridpur & 1000 & 8.66 & 2.68 \\
\hline 15 & Raiganj & 1000 & 4.57 & 2.68 \\
\hline 16 & Atghoria & 800 & 5.70 & 2.14 \\
\hline 17 & Shajahanpur & 600 & 2.55 & 1.61 \\
\hline 18 & Sonatola & 600 & 4.33 & 1.61 \\
\hline 19 & Kamarkhanda & 500 & 6.46 & 1.34 \\
\hline 20 & Dhunat & 400 & 2.05 & 1.07 \\
\hline \multirow[t]{2}{*}{21} & Adamdighi & 200 & 1.57 & 0.54 \\
\hline & Bogra region & 37300 & 5.58 & 100.00 \\
\hline
\end{tabular}

in April and cold injury at reproductive stage. Diversified cropping pattern may be resort for the farmer as a coping strategy with flood related risk (Mandal and Bezbaruah, 2013) but scope of diversification is limited due to environmental and climatic condition (FAO, 1988).

\section{Crop diversity and cropping intensity}

Higher number of available crops under cultivation in an area dictates its higher diversity. Number of cropping patterns is also a gross indicator of crop diversity. A total of 177 cropping patterns were identified in the whole area of Bogra region under this investigation. The highest number of cropping patterns was identified 36 in Kazipur upazila of Sirajganj district and that was 34 in Sonatola upazila in Bogra district (Table 15). The lowest number of cropping patterns was identified six in Nandigram followed by nine in Dubchachia and Kahalu upazila. The higher number of cropping patterns is generally related to higher level of diversity indices for cropping pattern. The upazilas having lower number of cropping patterns were related to either low land area or water logging or both. The highest value of diversity index for cropping pattern was found 0.950 in Bera upazila that was followed by 0.912 in Chatmohar upazila. The lowest CDI was reported 0.718 in Raiganj of Sirajganj district followed by 0.734 in Kalai upazila in Joypurhat. The highest value of CDI was observed 0.978 in Pabna sadar followed by 0.972 in Bera upazila. The range of cropping intensity values was recorded $183-291 \%$. The maximum value was for Khetlal upazila of Joypurhat district and minimum for Bera upazila of Pabna district. As a whole the CDI of Bogra region was calculated 0.966 and the average cropping intensity at regional level was $234 \%$. In a simultaneous study, the investigators identified 316 cropping patterns for whole Bangladesh; where the CDI value was 0.952 at national level and the national average of cropping intensity was $200 \%$ (Nasim et al, 2017). Diversification of crops helps risk reduction as diversification allows a producer to balance low price in one or two crops with reasonable prices in other. (Blade and Slinkard, 2002). The farmers of Kerala diversified their cropping pattern to minimize risk of crop failures and price fluctuations (Mahesh, 1999). 
Table 15. Crop diversity and cropping intensity in Bogra region, 2014-15.

\begin{tabular}{|c|c|c|c|c|c|c|}
\hline & Upazila & $\begin{array}{c}\text { No. of identified } \\
\text { pattern }\end{array}$ & No. of crop & $\begin{array}{l}\text { Diversity index for } \\
\text { cropping pattern }\end{array}$ & $\begin{array}{c}\text { Crop diversity } \\
\text { index (CDI) }\end{array}$ & C.I. (\%) \\
\hline 01 & Adamdighi & 14 & 13 & 0.762 & 0.909 & 261 \\
\hline 02 & Bogra & 16 & 18 & 0.675 & 0.879 & 282 \\
\hline 03 & Dhunat & 22 & 17 & 0.535 & 0.794 & 215 \\
\hline 04 & Dubchachia & 9 & 13 & 0.827 & 0.866 & 277 \\
\hline 05 & Gabtali & 20 & 16 & 0.614 & 0.831 & 218 \\
\hline 06 & Kahalu & 9 & 11 & 0.677 & 0.878 & 274 \\
\hline 07 & Nandigram & 6 & 7 & 0.692 & 0.893 & 276 \\
\hline 08 & Sariakandi & 19 & 17 & 0.852 & 0.929 & 205 \\
\hline 09 & Sherpur & 32 & 15 & 0.660 & 0.863 & 227 \\
\hline 10 & Shibganj & 16 & 15 & 0.499 & 0.810 & 282 \\
\hline 11 & Shajahanpur & 22 & 14 & 0.761 & 0.905 & 241 \\
\hline 12 & Sonatola & 34 & 22 & 0.835 & 0.936 & 246 \\
\hline 13 & Akkelpur & 19 & 15 & 0.647 & 0.859 & 260 \\
\hline 14 & Joypurhat & 14 & 15 & 0.795 & 0.920 & 259 \\
\hline 15 & Kalai & 12 & 13 & 0.270 & 0.734 & 289 \\
\hline 16 & Khetlal & 17 & 12 & 0.402 & 0.783 & 291 \\
\hline 17 & Panchbibi & 13 & 10 & 0.768 & 0.908 & 251 \\
\hline 18 & Atghroria & 28 & 13 & 0.868 & 0.949 & 237 \\
\hline 19 & Bera & 29 & 20 & 0.950 & 0.972 & 183 \\
\hline 20 & Bhangura & 16 & 13 & 0.859 & 0.931 & 196 \\
\hline 21 & Chatmohar & 20 & 16 & 0.912 & 0.961 & 218 \\
\hline 22 & Faridpur & 11 & 14 & 0.816 & 0.906 & 200 \\
\hline 23 & Iswardi & 18 & 17 & 0.904 & 0.954 & 247 \\
\hline 24 & Pabna sadar & 34 & 21 & 0.942 & 0.978 & 256 \\
\hline 25 & Santhia & 25 & 16 & 0.891 & 0.962 & 274 \\
\hline 26 & Sujanagar & 28 & 19 & 0.843 & 0.922 & 201 \\
\hline 27 & Belkuchi & 14 & 14 & 0.759 & 0.894 & 219 \\
\hline 28 & Chowhali & 26 & 26 & 0.901 & 0.944 & 196 \\
\hline 29 & Kazipur & 36 & 21 & 0.845 & 0.940 & 190 \\
\hline 30 & Kamarkhanda & 19 & 18 & 0.832 & 0.919 & 227 \\
\hline 31 & Raiganj & 21 & 17 & 0.425 & 0.718 & 203 \\
\hline 32 & Shahjadpur & 19 & 16 & 0.703 & 0.870 & 217 \\
\hline 33 & Sirajganj & 25 & 21 & 0.831 & 0.917 & 206 \\
\hline 34 & Tarash & 28 & 22 & 0.799 & 0.899 & 198 \\
\hline \multirow[t]{2}{*}{35} & Ullapara & 26 & 18 & 0.777 & 0.900 & 209 \\
\hline & Bogra region & 177 & 35 & 0.919 & 0.966 & 234 \\
\hline
\end{tabular}

\section{CONCLUSION}

The cropping intensity of the Bogra region was higher than the national average. Boro-Fallow-T. Aman, Potato-Boro-T. Aman, Mustard-BoroFallow, Mustard-Boro-T. Aman and single Boro were the dominant cropping patterns in the region. Exclusive rice area is about three folds of exclusive non-rice area. In Bogra region crop diversity is much wider than that of other regions. Based on the findings of the study, the following recommendations were made.
- Initiative to be taken to increase productivity of exclusive rice based cropping pattern.

- Effort might be given so that a portion of double-rice area could be brought under Potato-Boro-T. Aman and/or MustardBoro-T. Aman cropping systems.

- In the single Boro area suitable vegetables might be grown on floating bed system in wet season.

- The upazilas having unique or exceptional cropping patterns with large area coverage 
might be studied in-depth to extrapolate to similar environments.

- Scope might be explored for the establishment of agro-food industry on the basis of potato crop.

\section{REFERENCES}

Agrawal, D J and A H Kassam. 1976. The importance of multiple cropping in increasing world food supplies. American Society of Agronomy, Madison, Wisconsin. 27: 2-3.

Blade, S F and A E Slinkard 2002. New Crop Development: The Canadian Experience. In: Trends in New Crops and New Uses. J Janick and A Whipkey (Editors). ASHS Press, Alexandria.

Das, Anup., GI Ramkrushna, GS Yadav, J Layek, C Debnath, B U Choudhury, K P Mohaptara, S V Ngachan and S Das. 2015. Capturing traditional practices of rice based farming systems and identifying interventions for resource conservation and food security in Tripura, India. Applied Ecology and Environmental Sciences. 3(4): 100-107.

FAO, 1988. Land Resources Appraisal of Bangladesh for Agricultural Development- Report 2: Agroecological regions of Bangladesh. Food and Agriculture Organization of the United Nations, Rome, Italy. $570 \mathrm{p}$.

Gadge, S S. 2003. Influence of changes in cropping pattern on farmers' economic status. Indian J. Ext. Edu. 39(1\&2): 99-101.

Jackson, B R, A Yantasast, C Prechachat, M A Chowdhury and S M H Zaman. 1972. Breeding rice for deepwater areas. International Rice Research Institute, Rice Breeding, Los Baňos, Philippines. in:517-528.

Kshirsagar, K G, S Pandey and M R Bellon. 1997. Farmers' perception, varietal characteristics and technology adoption: the case of rainfed village in eastern India. Discussion paper 5/97. Social Sciences Division, International Rice Research Institute. Los Baňos, Laguna, Philippines.

Mahesh, R. 1999. Causes and consequences of change in cropping pattern: A location specific study. Discussion Paper No. 11, Kerala Research Programme on Local Level Development, Centre for Development Studies, Thiruvananthapura.

Mandal, R and M P Bezbaruah. 2013. Diversification of cropping pattern: its determinants and role in flood affected agriculture of Assam Plains. Ind. Jn. of Agri. Econ. 68(2): 169-181.

Muttaleb, M A, S M Shahidullah, M Nasim and A Saha. 2017. Cropping systems and land use in Sylhet region. Bangladesh Rice J. 21(2): 283-298.

Nasim, M, S M Shahidullah, A Saha, M A Muttaleb, T L Aditya, M A Ali and M S Kabir. 2017. Distribution of Crops and Cropping Patterns in Bangladesh. Bangladesh Rice J. 21(2): 1-55.

Neena, D. 1998. Interstate variation in cropping pattern in India.Indian J. Regi. Sci. 30(2): 57-69.

Rashid, M H, A H Khan and M M Alam. 2005. Cropping systems dynamics in greater Khustia. J. Bangladesh Agril. Univ. 3(2):213-238.

Shahidullah, S M, M Nasim, M K Quais and A Saha. 2017. Diversity of Cropping Systems in Chittagong Region. Bangladesh Rice J. 21(2): 109-123.

Shriar, A J. 2000. Agricultural intensity and its measurement in frontier regions. Agroforestry Systems. 49 (3): 301318. 
Appendix 1. List of cropping patterns in Bogra region, 2014-15.

\begin{tabular}{|c|c|c|c|c|c|}
\hline & Cropping pattern & Area (ha) & & Cropping pattern & Area (ha) \\
\hline 001 & Boro-Fallow-T. Aman & 146250 & 067 & Chilli-Aus-Fallow & 1210 \\
\hline 002 & Potato-Boro-T. Aman & 88610 & 068 & Fallow-Fallow-Blackgram & 1210 \\
\hline 003 & Mustard-Boro-Fallow & 50940 & 069 & Potato-Maize-T. Aman & 1200 \\
\hline 004 & Mustard-Boro-T. Aman & 40110 & 070 & Vegetab-Vegetab-T. Aman & 1030 \\
\hline 005 & Boro-Fallow-Fallow & 37300 & 071 & Garlic-Aus-T. Aman & 1010 \\
\hline 006 & Boro-Aus-T. Aman & 19700 & 072 & Grasspea-Fallow-Fallow & 1005 \\
\hline 007 & Boro-B. Aman & 18650 & 073 & Vegetab-Onion-Aus & 1000 \\
\hline 008 & Vegetab-Vegetab-Vegetab & 16030 & 074 & Wheat-Sesame-Fallow & 1000 \\
\hline 009 & Wheat-Jute-T. Aman & 14540 & 075 & Lentil-Sesame+B. Aman & 980 \\
\hline 010 & Onion-Jute-Fallow & 10080 & 076 & Vegetab-Jute-T. Aman & 980 \\
\hline 011 & Onion-Jute-T. Aman & 9330 & 077 & Lentil-Jute-T. Aman & 975 \\
\hline 012 & Wheat-B. Aman & 7920 & 078 & Grasspea-Sesame-T. Aman & 970 \\
\hline 013 & Boro-Jute-T. Aman & 7020 & 079 & Vegetab-Fallow-Fallow & 900 \\
\hline 014 & Lentil-Jute-Fallow & 6650 & 080 & Wheat-Fallow-Blackgram & 900 \\
\hline 015 & Grasspea-B. Aman & 6470 & 081 & Boro-Sesbania-T. Aman & 880 \\
\hline 016 & Mustard-Boro-B. Aman & 5000 & 082 & Lentil-Sesame-Fallow & 810 \\
\hline 017 & Vegetab-Boro-T. Aman & 4760 & 083 & Grasspea-Jute-T. Aman & 800 \\
\hline 018 & Wheat-Aus-Fallow & 4700 & 084 & Groundnut-F-Blackgram & 800 \\
\hline 019 & Chilli-Jute-Fallow & 4620 & 085 & Mustard-B.Aus+B. Aman & 800 \\
\hline 020 & Groundnut-Fallow-Fallow & 4280 & 086 & Lentil-B. Aman & 790 \\
\hline 021 & Wheat-Jute-Fallow & 4090 & 087 & S.Potato-Jute-Fallow & 780 \\
\hline 022 & Boro-Vegetab(Float/Norm) & 4000 & 088 & Potato-Boro-Fallow & 750 \\
\hline 023 & Vegetab-Vegetab-Fallow & 3730 & 089 & Onion-Aus-Blackgram & 740 \\
\hline 024 & Onion-B. Aman & 3650 & 090 & Chilli-Fallow-Fallow & 710 \\
\hline 025 & Wheat-Aus-T. Aman & 3630 & 091 & Garlic-Jute-T. Aman & 700 \\
\hline 026 & Lentil-Aus-T. Aman & 3340 & 092 & Mustard-Boro-Jute & 700 \\
\hline 027 & Maize-Jute-Fallow & 3300 & 093 & Wheat-Maize-T. Aman & 700 \\
\hline 028 & Garlic-B. Aman & 3100 & 094 & S.Potato-Fallow-Fallow & 675 \\
\hline 029 & Onion-Vegtab-Vegetab & 3100 & 095 & Boro-Aus-Fallow & 670 \\
\hline 030 & Blackgram-B. Aman & 2950 & 096 & Maize-B. Aman & 650 \\
\hline 031 & Grasspea-Boro-Fallow & 2950 & 097 & Maize-Fallow-T. Aman & 640 \\
\hline 032 & Mustard-Jute-T. Aman & 2700 & 098 & Coriander-Vegetab-Fallow & 630 \\
\hline 033 & Grasspea-Boro-B. Aman & 2600 & 099 & Potato-Sesame-T. Aman & 600 \\
\hline 034 & Mustard-Boro-Aus & 2560 & 100 & Grasspea-Jute-Fallow & 550 \\
\hline 035 & Maize-Fallow-Fallow & 2520 & 101 & Groundnut-Jute-T. Aman & 500 \\
\hline 036 & Wheat-Sesame-T. Aman & 2470 & 102 & Sesame-Fallow-Blackgram & 500 \\
\hline 037 & Boro-Sesbania-Fallow & 2450 & 103 & Wheat-Jute-Blackgram & 500 \\
\hline 038 & Mustard-Boro-Aus-T. Aman & 2330 & 104 & Chilli-Aus-T. Aman & 430 \\
\hline 039 & Chilli-Jute-T. Aman & 2300 & 105 & Garlic-Jute-Fallow & 430 \\
\hline 040 & Mustard-B. Aman & 2300 & 106 & Garlic-Fallow-T. Aman & 420 \\
\hline 041 & Maize-Jute-T. Aman & 2255 & 107 & Boro-Aus-Blackgram & 410 \\
\hline 042 & Potato-Boro-Aus-T. Aman & 2250 & 108 & Grasspea-Sesbania-Fallow & 400 \\
\hline 043 & Mustard-Aus-T. Aman & 2200 & 109 & Mustard-Aus-Blackgram & 400 \\
\hline 044 & Onion-Sesame-T. Aman & 2200 & 110 & Mustard-Mungbean-T. Aman & 400 \\
\hline 045 & Wheat-Vegetab-Vegetab & 2100 & 111 & Pea-B. Aman & 400 \\
\hline 046 & Vegetab-Aus-Fallow & 2060 & 112 & Groundnut-Millet(kaon)-F & 380 \\
\hline 047 & B.gram(Fod)-Boro-B. Aman & 2000 & 113 & Vegetab-Jute-Vegetab & 380 \\
\hline 048 & Wheat-Mungbean-T. Aman & 1990 & 114 & Onion-Sesame-Fallow & 350 \\
\hline 049 & Boro-Fallow-Blackgram & 1960 & 115 & Garlic-Vegetab-Vegetab & 345 \\
\hline 050 & Onion-Aus-T. Aman & 1910 & 116 & Maize-Maize-T. Aman & 330 \\
\hline 051 & Boro-Jute-Fallow & 1900 & 117 & Maize-Aus-Fallow & 320 \\
\hline 052 & Onion-Sesame+B. Aman & 1800 & 118 & Mustard-Sesame-T. Aman & 320 \\
\hline 053 & Vegetab-Fallow-T. Aman & 1790 & 119 & Groundnut-Sesame-Fallow & 300 \\
\hline 054 & Millet(kaon)+Sesame-F & 1720 & 120 & Lentil-Aus-Fallow & 300 \\
\hline 055 & Grasspea-Sesame+B. Aman & 1700 & 121 & Maize-Sesame-T. Aman & 300 \\
\hline 056 & Lentil-Sesame-T. Aman & 1680 & 122 & Potato-Boro-Vegetab & 300 \\
\hline 057 & Potato-Vegetab-T. Aman & 1670 & 123 & Potato-Maize-Aus & 300 \\
\hline 058 & Vegetab-Aus-T. Aman & 1665 & 124 & Potato-Maize-Aus-Vegetab & 300 \\
\hline 059 & Chilli-Vegetab-Fallow & 1650 & 125 & Vegetab-Boro-Jute & 300 \\
\hline 060 & Wheat-Fallow-T. Aman & 1560 & 126 & Pea-Aus-Vegetab & 280 \\
\hline 061 & Fallow-Fallow-T. Aman & 1550 & 127 & Lentil-Vegetab-Vegetab & 270 \\
\hline 062 & Millet(kaon)-F-T. Aman & 1500 & 128 & Wheat-Fallow-Fallow & 230 \\
\hline 063 & Potato-Maize-Vegetab & 1500 & 129 & Boro-Vegetab-T. Aman & 200 \\
\hline 064 & Fallow-Sesame+B. Aman & 1400 & 130 & Potato-Fallow-T. Aman & 200 \\
\hline 065 & Potato-Jute-T. Aman & 1280 & 131 & Sesame-Aus-Fallow & 200 \\
\hline \multirow[t]{2}{*}{066} & Vegetab-Jute-Fallow & 1240 & 132 & Vegetab-Fallow-Blackgram & 200 \\
\hline & & & $133-177$ & Other 45 patterns (Table 9) & 3045 \\
\hline
\end{tabular}

90 Islam et al 